\title{
Water quality evaluation using water quality index and multivariate methods, Beheshtabad River, Iran
}

\author{
Ehsan Fathi ${ }^{1} \cdot$ Rasool Zamani-Ahmadmahmoodi $^{2}{ }^{[0} \cdot$ Rafat Zare-Bidaki $^{1}$
}

Received: 21 January 2018 / Accepted: 16 October 2018 / Published online: 26 October 2018

(c) The Author(s) 2018

\begin{abstract}
Rivers are critical to agriculture, industry, and the needs of humans and wildlife. This study evaluates the water quality of the Beheshtabad River in Iran's Chaharmahal and Bakhtiari Province, using water quality index and multivariate statistical methods. Nitrate, temperature, phosphate, turbidity, dissolved oxygen, biological oxygen demand, electrical conductivity, total solids, and $\mathrm{pH}$ were measured at five selected stations along the river over 6 months using standard methods. Water quality index results demonstrated that water quality varied in the selected stations between average and good and that pollution in this section of the Beheshtabad River increases from upstream to downstream. Clustering and principal component analysis were also utilized. Multivariate statistical methods were used to analyze water conditions for efficient management of surface water quality. Agricultural fertilizers, upstream wastewater discharge, and fish farms constitute the main elements that decrease the water quality of the Beheshtabad River. To preserve this water resource against pollution, the implementation of stringent rules and guidelines are needed to enhance health and preserve water resources for future generations.
\end{abstract}

Keywords Water quality index · Multivariate statistical methods $\cdot$ Beheshtabad River $\cdot$ Chaharmahal and Bakhtiari Province $\cdot$ Iran

\section{Introduction}

For human beings, rivers have always been vital, and to use water resources, cities and industrial as well as agricultural centers have been established close to them. With the passage of time, development of communities, and increased use of water resources, pressures upon controlling water resources and detection of abnormal changes in water quality conditions have increased (Sánchez et al. 2007). Population growth, environmental pollution from discharge of urban and industrial sewage, and runoff have increased pollution and limited available water resources (Simeonov et al. 2003; Sánchez et al. 2007). Monitoring and controlling surface waters are necessary and vital to assure the availability of

Rasool Zamani-Ahmadmahmoodi

zamani@nres.sku.ac.ir; rasoolzamani@yahoo.com

1 Department of Rangeland and Watershed Management, Faculty of Natural Resources and Earth Science, Shahrekord University, P.O. Box 115, Shahrekord, Iran

2 Department of Fisheries and Environmental Sciences, Faculty of Natural Resources and Earth Science, Shahrekord University, P.O. Box 115, Shahrekord, Iran high-quality water for its many uses (Bollinger et al. 1999; Sánchez et al. 2007). One of simple methods that can recount the qualitative conditions of water is the use of water quality indexes (Hoseinzadeh et al. 2015; Barakat et al. 2018). The National Sanitation Foundation Water Quality Index (NSFWQI) is one of the popular indexes classifying surface water quality that is determined based on temperature, phosphate, nitrate, dissolved oxygen, total solids, biological oxygen demand, $\mathrm{pH}$, and fecal coliform bacteria. This index is very popular and considered comprehensive for the qualitative classification of surface water. With its implementation, it is likely to produce an appropriate view regarding water quality of rivers (Bordalo et al. 2001; Sánchez et al. 2007). Multivariate statistical methods such as principal component analysis (PCA) and cluster analysis (CA) are used in numerous studies to identify potential pollutants (Gholami and Srikantaswamy 2009; Fan et al. 2010; Massoud 2012; Lin et al. 2017; Misaghi et al. 2017; Zamani-Ahmadmahmoodi et al. 2017).

PCA is a multivariate statistical technique, and in the cases where large amount of data are available, it is a suitable means to decrease the data (Noori et al. 2009, 2010). In addition, $\mathrm{CA}$ is one of the multivariate statistical techniques 
used to determine relative similarity in the homogeneity of measured parameters (Shrestha and Kazama 2007). The Beheshtabad River is one of the most important rivers in Iran. It provides water for several purposes including agricultural activities, fish farms, hydroelectric power plants, and drinking water. This is why monitoring the water quality of this river is very important. In the present study, the water quality of the Beheshtabad River has been evaluated using NSFWQI, CA, and PCA in selected sampling stations.

\section{Materials and methods}

The river of interest is located at the village of Beheshtabad, which comprises an area of 3866 square meters in Chaharmahal and Bakhtiari province in Iran. This area is located between $31^{\circ} 28^{\prime} \mathrm{N}$ and $32^{\circ} 56^{\prime} \mathrm{N}$ latitude and $50^{\circ} 36^{\prime} \mathrm{E}$ and $51^{\circ} 45^{\prime} \mathrm{E}$ longitude. There are many fish farms along this river that are very important in terms of economics of local communities. This river provides water for agricultural activities around it. Recently, an inter-basin water transfer project has been proposed to transfer water from this river to central area of Iran.

To obtain the required information to investigate the water quality of the Beheshtabad River, water was sampled monthly in five stations (Fig. 1). Stations were selected based on accessibility and pollution sources along the Beheshtabad River and one of its tributary. After collection, to avoid microbial degradation, the samples were held at $4{ }^{\circ} \mathrm{C}$ in a refrigerator without acid preservation. All samples were analyzed within $24 \mathrm{~h}$. The parameters of temperature (T), $\mathrm{pH}$, electrical conductivity (EC), and dissolved oxygen (DO) were measured using a Hach HQ40d portable meter. To analyze other parameters, such as phosphate $\left(\mathrm{PO}_{4}\right)$, nitrate $\left(\mathrm{NO}_{3}\right)$, total solids (TS), and biological oxygen demand (BOD), water samples were transferred to the laboratory and were analyzed using methods described in the American Public Health Association manual (APHA 1992).

In 1970, with the support of the US National Institutes of Health, Brown et al. (1970) presented a qualitative index based on a survey of many professionals in this field with different types of expertise. They first introduced 35 qualitative parameters and then selected nine parameters to create their qualitative index, NSFWQI (Brown et al. 1970). NSFWQI formula is as follows [Eq. (1)]:

NSFWQI $=\sum W i Q i$

NFSWQI: water quality index (0-100); Wi: weight of intended factor (0-1); $Q i$ : sub-index resulted from quality index curves (0-100) (Table 1).

The SPSS 17 was performed for analyzing the data. The suitability of data for PCA was evaluated by
Table 1 Water quality index values of rivers

\begin{tabular}{ll}
\hline Status & Value \\
\hline Very good & $90-100$ \\
Good & $70-90$ \\
Average & $50-70$ \\
Bad & $25-50$ \\
Very bad & $0-25$ \\
\hline
\end{tabular}

Kaiser-Meyer-Olkin (KMO) and Bartlett tests. In order to improve the relationship between inputs and primary factors as well as to achieve better resolutions, the Varimax method was used (Noori et al. 2010; Ouyang 2005; Ritters et al. 1995). To perform CA, averages of nine parameters for five stations were analyzed in MINITAB 17. The similarity between clusters and separating homogenous clusters were determined based on Euclidean distance. In this study, hierarchical CA was implemented for a set of normalized data with Ward's Method.

\section{Results and discussion}

The values of NSFWQI are presented in Table 2, which shows that the water quality during study period was observed to vary between average and good levels. The mean of this index for summer and autumn is presented in Fig. 2.

The mean of the surface water qualitative parameters in the five Beheshtabad River stations over the period of 6 months (Table 3) was used to determine the most important parameters using PCA (Table 4).

After conducting CA, the stations of interest were placed in three clusters (Fig. 3).

The distance between each of the selected stations in the clusters obtained from CA is the result of correlation and autocorrelation between surface water qualitative parameters. According to Fig. 3, given distance lower than 50, three clusters were extracted: The first cluster comprised stations 1 and 2 , the second cluster contained station 3 , and the third cluster incorporated stations 4 and 5 .

Results in Table 2 show that the best-quality water was sourced at station 3 in July, August, and December, while the worst was drawn at station 4 in September and October. Regarding the mean, the worst quality was found in September and the best in December. During the 6-month period, based on the water quality index values (Table 1), the quality in the first 5 months was average and was good only in December (Table 2).

Since the Beheshtabad River is exposed to tourism, low quality of water is caused by human factors and discharge of wastewater utilities. In station 2 in December, the water quality was good, and in other months, the quality was average, which was the result of illegal wastewater 
Fig. 1 Location of sampling points in the Beheshtabad River

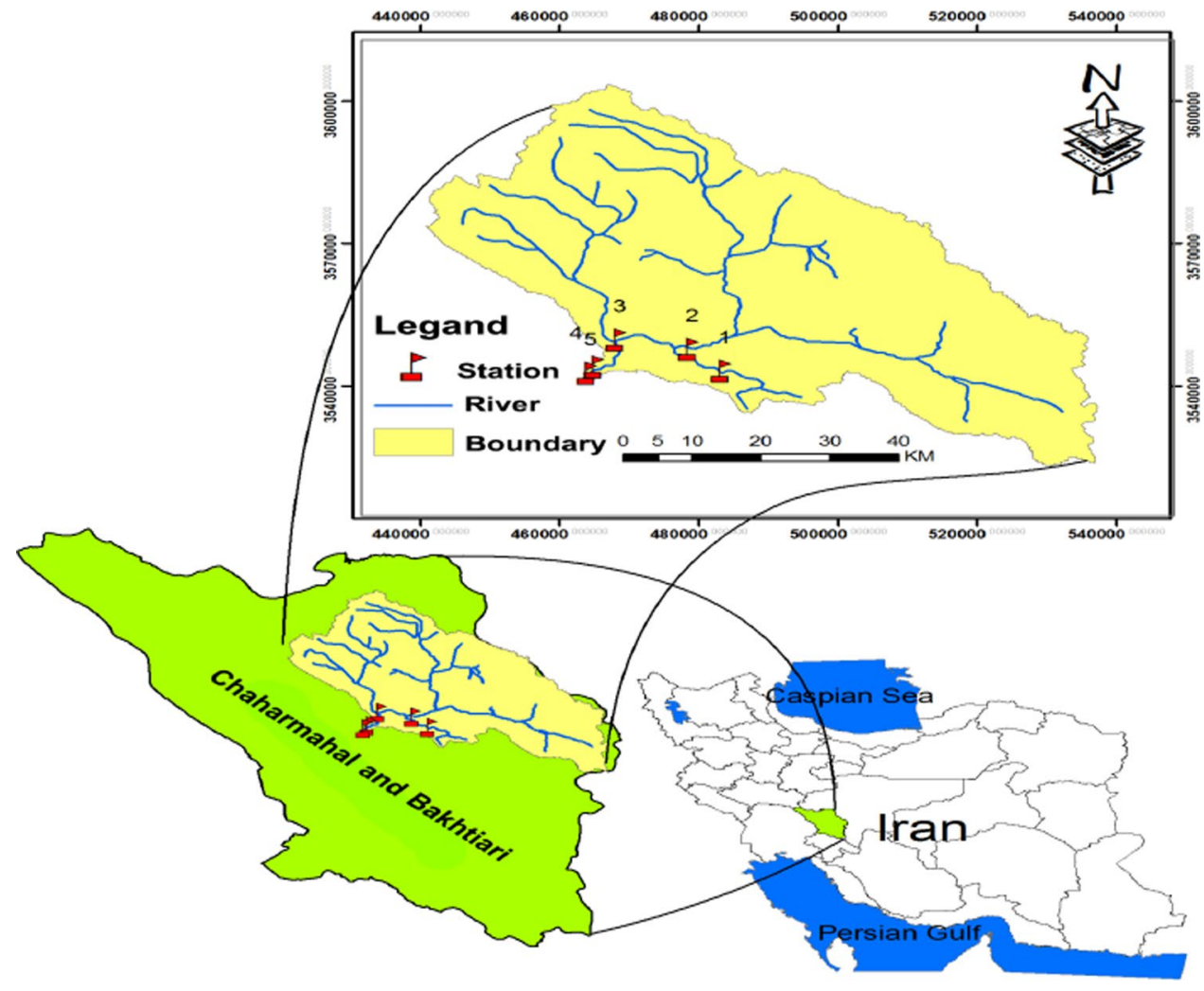

\begin{tabular}{lllllll}
\hline Station & July & August & September & October & November & December \\
\hline 1 & 65 & 64 & 64 & 62 & 65 & 68 \\
2 & 69 & 66 & 62 & 62 & 63 & 74 \\
3 & 75 & 75 & 70 & 64 & 74 & 75 \\
4 & 66 & 62 & 62 & 61 & 66 & 71 \\
5 & 72 & 63 & 64 & 62 & 61 & 67 \\
Mean & 69.4 & 66 & 64.4 & 62.2 & 65.8 & 71 \\
\hline
\end{tabular}

Table 2 Beheshtabad River water quality based on NSFWQI

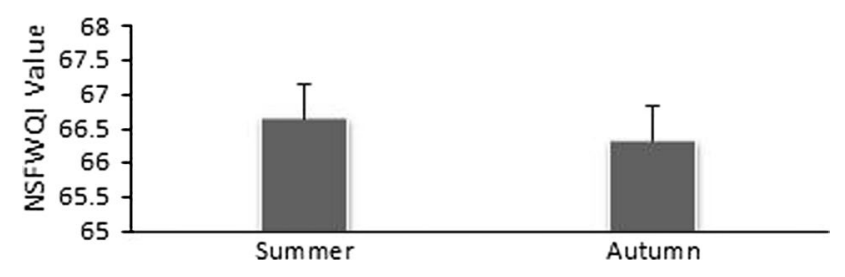

Fig. 2 Mean of NSFWQI in Summer and Autumn

discharge. In addition, other factors such as road construction, cultivation of gardens, agricultural activities around the river, and other human factors adversely affect the quality of this station. The water quality at station 3 in all months was better than that of the other stations, due to increased water flow, dilution and self-purification of agricultural pollutants, and most importantly, the entrance of Joneghan River to the Beheshtabad River at this station. Evaluation at station 4 in December and at station 5 in July showed good water quality, and other months had average quality. The reason for the high quality of water at station 5 is the lack of fish farm activities upstream of this station and within this month. In addition, the low quality of water in stations 4 and 5 in other months comes from agricultural activities and the entrance of wastewaters as well as rice water overflows, fish farms' activities, and discharge of wastewater due to the lack of facilities. Table 5 shows a comparison of water quality index in the Beheshtabad River with different rivers around the world.

In Table 6, the measured parameters with water pollution standard are presented. Water temperature in the study period was 4.9-23.5. One of the important quality parameters in water utilization is $\mathrm{pH}$. Its optimal values (see Table 6) are around 6.5-9.5. 
Table 3 Mean of surface water qualitative parameters of the Beheshtabad River

\begin{tabular}{llllllllll}
\hline Station & $\mathrm{T}\left({ }^{\circ} \mathrm{C}\right)$ & $\mathrm{TUR}(\mathrm{NTU})$ & $\mathrm{PO}_{4}(\mathrm{mg} / \mathrm{L})$ & $\mathrm{NO}_{3}(\mathrm{mg} / \mathrm{L})$ & $\mathrm{DO}(\mathrm{mg} / \mathrm{L})$ & $\mathrm{BOD}(\mathrm{mg} / \mathrm{L})$ & $\mathrm{EC}(\mu \mathrm{S} / \mathrm{cm})$ & $\mathrm{TS}(\mathrm{mg} / \mathrm{L})$ & $\mathrm{pH}$ \\
\hline 1 & 14.50 & 1.27 & 0.06 & 14.32 & 5.82 & 2.60 & 496.66 & 435.33 \\
2 & 14.10 & 1.86 & 0.07 & 21.46 & 8.63 & 3.23 & 556.50 & 495.00 & 8.41 \\
3 & 16.50 & 2.80 & 0.08 & 12.00 & 9.03 & 1.77 & 416.50 & 369.5 \\
4 & 14.96 & 3.12 & 0.20 & 29.16 & 9.46 & 3.41 & 675.00 & 550.33 \\
5 & 17.21 & 2.94 & 0.22 & 31.43 & 11.03 & 2.61 & 684.16 & 597.16 \\
\hline
\end{tabular}

Table 4 Rotation component matrix for physicochemical parameters in surface water samples from the Beheshtabad River

\begin{tabular}{lrr}
\hline Parameter & \multicolumn{2}{l}{ Component } \\
\cline { 2 - 3 } & 1 & 2 \\
\hline $\mathrm{T}$ & -0.235 & $\mathbf{0 . 9 0 2}$ \\
$\mathrm{TUR}$ & 0.223 & $\mathbf{0 . 9 1 3}$ \\
$\mathrm{PO}_{4}$ & 0.649 & $\mathbf{0 . 7 0 1}$ \\
$\mathrm{NO}_{3}$ & $\mathbf{0 . 8 9 1}$ & 0.435 \\
$\mathrm{DO}$ & 0.364 & $\mathbf{0 . 8 8 3}$ \\
$\mathrm{BOD}$ & $\mathbf{0 . 9 0 8}$ & 0.342 \\
$\mathrm{EC}$ & $\mathbf{0 . 9 3 3}$ & 0.312 \\
$\mathrm{TS}$ & $\mathbf{0 . 9 1 0}$ & 0.307 \\
$\mathrm{pH}$ & 0.444 & $\mathbf{0 . 7 4 5}$ \\
$\%$ of variance explained $(\%)$ & 64.679 & 64.679 \\
$\%$ of cumulative $(\%)$ & 64.679 & 90.472 \\
\hline
\end{tabular}

Bold values are significant at $>0.7$

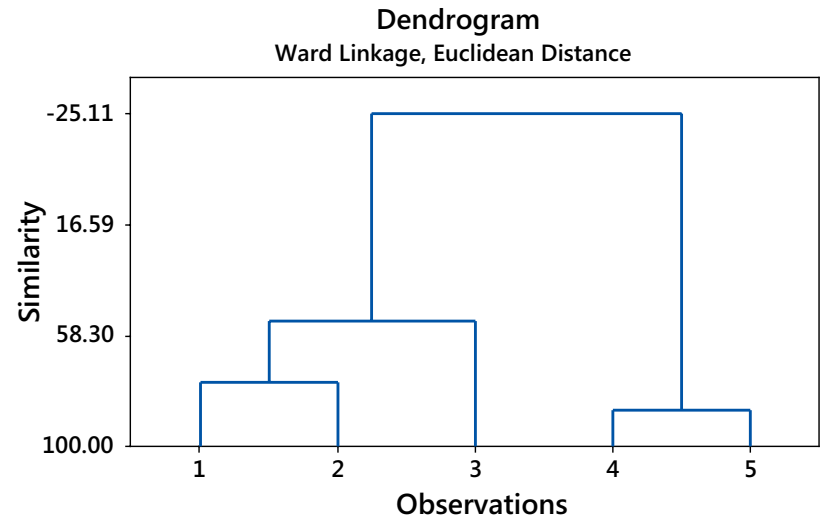

Fig. 3 Clustering of stations in the study area using clustering analysis

Table 5 Water quality index in the Beheshtabad River over 6 months compared to different rivers

\begin{tabular}{lcl}
\hline Resource & WQI & River \\
\hline Present study & $71-62.2$ & Beheshtabad River \\
Bordalo et al. (2006) & $67.1-47.3$ & Douro River \\
Sharama et al. (1996) & $80-61$ & Halali River \\
Hooshmand et al. (2008) & $65-50$ & Karoon River \\
\hline
\end{tabular}

The dissolved oxygen value in water is dependent on temperature, salinity, barometric pressure, and solids. Moreover, climatic conditions and chemical, biological, and microbial processes are effective in determining oxygen variation in water (Yang et al. 2007). In this study, in most of the downstream stations, due to increasing rains and water flows, the dissolved oxygen level increases. According to Table 6, the level of dissolved oxygen in all stations was optimal. The conductivity level in December was standard in all stations. In July, August, September, and October, in all stations except station 3 and in December except stations 1 and 3, conductivity levels are higher due to fish farm activities, industrial pollutants, and geological formations. The highest water quality in terms of BOD was seen in December and the lowest quality occurred in September. In station 3, in all months except September together with stations 1, 3 , and 4 in December, the water quality is high, as shown in Table 2. In all months, the water quality is low in other stations, because water is adversely affected by fish farms and agricultural wastewater. The nitrate levels in July and November in stations 1 and 3, in August and September in station 3, in October in station 1, and in December in stations 1, 2, 3, and 4 were at optimal levels, but other stations were polluted by nitrate. The reason can be the runoff from farmlands and gardens, the use of chemical fertilizers, activities of fish farms, and the wastewater flowing into the river. Generally, the phosphate concentration has been higher from upstream to downstream stations in all stations except station 3 in July and August, due to the activity of fish farms. However, as seen in Table 6, the Beheshtabad River is not contaminated by phosphate. In the first 3 months of the 6-month test period, the total amounts of solids showed an increase-decrease trend from upstream to downstream. In the third month and at station 3, the lowest and highest values were observed in the last stations. However, the total solids are at standard level, as displayed in Table 6. Generally, the reasons for increased solids in downstream stations are construction activities and plowing of agricultural land around the river. Since solid materials increase in the river water during autumn, the water quality decreases in this season compared to summer (Fig. 2).

The mean of the surface water qualitative parameters in the five Beheshtabad River stations over the period of 
Table 6 Surface water pollution standards based on various resources

\begin{tabular}{llll}
\hline Parameter (unit) & Standard & Resource & $\begin{array}{l}\text { Levels in } \\
\text { Beheshtabad } \\
\text { River }\end{array}$ \\
\hline $\mathrm{pH}(-)$ & & Boyd and Gautier (2000) \\
$\mathrm{TS}(\mathrm{mg} / \mathrm{L})$ & 1000 & World Health Organization (1998) & $9.37-7.11$ \\
$\mathrm{DO}(\mathrm{mg} / \mathrm{L})$ & $5>$ & Boyd and Gautier (2000) & $900-267$ \\
$\mathrm{BOD}(\mathrm{mg} / \mathrm{L})$ & $2-0$ very clean & EPA (1996) & $13.35-5.21$ \\
& $5-2$ relatively pol- & & $4.58-1.24$ \\
& luted & & \\
& $5<$ severely pol- & & \\
$\mathrm{NO}_{3}(\mathrm{mg} / \mathrm{L})$ & 16.9 & Schwartz and Boyd (1994) & $47.63-7.46$ \\
$\mathrm{PO}_{4}(\mathrm{mg} / \mathrm{L})$ & 0.1 & EPA (1996) & $0.392-0.015$ \\
$\mathrm{TUR}(\mathrm{N} . \mathrm{T} . \mathrm{U})$ & 5 & World Health Organization (1998) & $6.6-0.62$ \\
$\mathrm{EC}(\mu \mathrm{s} / \mathrm{cm})$ & $500-150$ & Kelly et al. 1998 & $802-307$ \\
\hline
\end{tabular}

6 months (Table 3) was used to cluster of stations in the study area. In Fig. 3, in cluster 1, which includes stations 1 and 2, the mean of EC and nitrate is higher than standard level in station 2. In addition, BOD levels in both stations reflected polluted waters. Other parameters have suitable condition compared to standard level. In cluster 2, which includes station 3, all parameters are in good condition. In cluster 3, which includes stations 4 and 5, phosphate and nitrate parameters in both stations were higher than standard. In addition, with the exception of BOD values, other parameters were in the standard range.

As demonstrated in Table 4, PCA factors are the main factors and express $90.472 \%$ of changes or variance. The first factor shows $64.679 \%$ of the variance, is introduced as the most important factor justifying water quality changes, and includes TS, EC, BOD, and $\mathrm{NO}_{3}$. The second parameter shows $25.793 \%$ of variance and includes $\mathrm{T}$, phosphate, DO, and $\mathrm{pH}$.

\section{Conclusions}

1. The results of this study show that according to water quality index standards, the quality of the Beheshtabad River did not vary much during the 6-month study period. However, pollution did increase from upstream to downstream.

2. According to CA, separate water quality evaluations of stations were based on surface water quality parameters that are located in three clusters. This clustering makes the achievement of surface water quality management easier. The analysis of PCA shows the importance of parameters in pollution studies, so that parameters that are more important are in factor 1 and less important ones are in the second factor.
3. By conducting analyses and investigating the results, it can be concluded that with wastewater from agricultural activities, gardens, fish farms, construction activities, and the resultant wastewater discharge, the Beheshtabad River's water quality has declined.

4. This study showed the efficiency of multivariate statistical techniques and water quality index to analyze and interpret a dataset for effective evaluation of surface waters.

5. To preserve this water resource against pollution, the implementation of stringent rules and guidelines are needed to enhance health and preserve water resources for future generations.

Acknowledgements This research was supported by the Shahrekord University, Iran.

\section{Compliance with ethical standards}

Conflict of interest The authors declare that there are no conflicts of interest regarding the publication of this manuscript.

Open Access This article is distributed under the terms of the Creative Commons Attribution 4.0 International License (http://creativeco mmons.org/licenses/by/4.0/), which permits unrestricted use, distribution, and reproduction in any medium, provided you give appropriate credit to the original author(s) and the source, provide a link to the Creative Commons license, and indicate if changes were made.

\section{References}

APHA (1992) Standard method for examination of water and wastewater, 18th edn. American Public Health Association, Washington

Barakat A, Meddah R, Afdali M, Touhami F (2018) Physicochemical and microbial assessment of spring water quality for drinking 
supply in Piedmont of Béni-Mellal Atlas (Morocco). Phys Chem Earth Parts A/B/C 104:39-46

Bollinger JE, Steinberg LJ, Harrison MJ et al (1999) Comparative analysis of nutrient data in the lower Mississippi River. Water Res 33:2627-2632

Bordalo AA, Nilsumranchit W, Chalermwat K (2001) Water quality and uses of the Bangpakong River (Eastern Thailand). Water Res 35:3635-3642

Bordalo AA, Teixeira R, Wiebe WJ (2006) A water quality index applied to an international shared river basin: the case of the Douro River. Environ Manag 38:910-920

Boyd CE, Gautier D (2000) Effluent composition and water quality standards. Advocate 3:61-66

Brown RM, McClelland NI, Deininger RA, Tozer RG (1970) GA water quality index: Do we dare? Water Sew Works 117:339-343

Environmental Protection Agency (EPA) (1996) Quality criteria for waters, Washington, DC

Fan X, Cui B, Zhao H et al (2010) Assessment of river water quality in Pearl River Delta using multivariate statistical techniques. Procedia Environ Sci 2:1220-1234

Gholami S, Srikantaswamy S (2009) Statistical multivariate analysis in the assessment of river water quality in the vicinity of KRS Dam, Karnataka, India. Nat Resour Res 18:235-247

Hooshmand A, Delgandi M, Sied Kaboli H (2008) Zoning of water quality on Karoon river bases on WQI index with GIS. In: 2nd congress on environmental engineering. Proceedings. Tehran University (in Persian)

Hoseinzadeh E, Khorsandi H, Wei C, Alipour M (2015) Evaluation of Aydughmush river water quality using the national sanitation foundation water quality index (NSFWQI), river pollution index (RPI), and forestry water quality index (FWQI). Desalin Water Treat 54(11):2994-3002

Kelly TR, Herida J, Mothes J (1998) Sampling of the Mackinaw River in central Illinois for physicochemical and bacterial indicators of pollution. Trans Ill State Acad Sci 91:145-154

Lin Y, Han P, Huang Y, Yuan GL, Guo X, Li J (2017) Source identification of potentially hazardous elements and their relationships with soil properties in agricultural soil of the Pinggu district of Beijing, China: Multivariate statistical analysis and redundancy analysis. J Geochem Explor 173:110-118

Massoud MA (2012) Assessment of water quality along a recreational section of the Damour River in Lebanon using the water quality index. Environ Monit Assess 184:4151-4160

Misaghi F, Delgosha F, Razzaghmanesh M, Myers B (2017) Introducing a water quality index for assessing water for irrigation purposes: a case study of the Ghezel Ozan River. Sci Total Environ 589:107-116

Noori R, Abdoli MA, Jalili Ghazizade M et al (2009) Comparison of neural network and principal component-regression analysis to predict the solid waste generation in Tehran, Iran. J Public Health 38:74-84 (In Persian)

Noori R, Khakpour A, Omidvar B et al (2010) Comparison of ANN and principal component analysis-multivariate linear regression models for predicting the river flow based on developed discrepancy ratio statistic. Expert Syst Appl 37:5856-5862 (In Persian)

Ouyang Y (2005) Evaluation of river water quality monitoring stations by principal component analysis. Water Res 39:2621-2635

Ritters KH, O'Neill RV, Hunsaker CT et al (1995) A factor analysis of landscape pattern and structure metrics. Landsc Ecol 10:23-39

Sánchez E, Colmenarejo MF, Vincente J et al (2007) Use of the water quality index and dissolved oxygen deficit as simple indicators of watersheds pollution. Ecol Indic 7:315-328

Schwartz MF, Boyd CE (1994) Channel catfish pond effluents. Prog Fish Cult 56:273-281

Sharama RK, Gupta SS, Jain OP (1996) Water quality index and aspects of pollution in Halali River of Bhopal region (Madhya Pradesh), India. J Ecotoxicol Environ Monit 6:181-187

Shrestha S, Kazama F (2007) Assessment of surface water quality using multivariate statistical techniques: a case study of the Fuji river basin, Japan. J Environ Model Softw 22:464-475

Simeonov V, Stratis JA, Samara C et al (2003) Assessment of the surface water quality in Northern Greece. Water Res 37:4119-4124

World Health Organization (1998) Guidelines for drinking water quality, 2nd edn. WHO, Geneva

Yang HJ, Shen ZM, Zhang JP et al (2007) Water quality characteristics along the course of the Huangpu River (China). J Environ Sci 19:1193-1198 (China)

Zamani-Ahmadmahmoodi R, Jafari A, Alibeygi-Beni H (2017) Potential ecological risk assessment, enrichment, geoaccumulation, and source identification of metals in the surface sediments of Choghakhor Wetland, Iran. Environ Earth Sci 76(11):398

Publisher's Note Springer Nature remains neutral with regard to jurisdictional claims in published maps and institutional affiliations. 